\title{
Wpływ regulacji technicznej na równowagę pionową koryta Wisły na przedpolu Karpat
}

\author{
Impact of Technical Regulation on the Vistula Channel Vertical Balance in the Carpathian \\ Foreland
}

\author{
Jadwiga Gorajska \\ Instytut Geografii, Uniwersytet Pedagogiczny im. KENw Krakowie, jadwiga.gorajska@gmail.com
}

Zarys treści: $\mathrm{W}$ artykule zaprezentowano wyniki obliczeń pionowych zmian położenia dna koryta Wisły na przedpolu Karpat w ostatnich 150 latach. Badaniami objęto 31 profili wodowskazowych na odcinku rzeki między Goczałkowicami i Puławami. Analizę zmian w pionowym położeniu dna koryta Wisły przeprowadzono w oparciu o ogólnie przyjęte założenie, że tendencja w przebiegu minimalnych rocznych stanów wody na posterunku wodowskazowym w wieloleciu odzwierciedla pogłębianie lub wypłycanie, a także pionową stabilizację koryta w tym przedziale czasu. Celem pracy jest wskazanie skutków prac regulacyjnych, które rozpoczęły się na badanym odcinku Wisły około 1840 r. Szczególną uwagę zwrócono na zmiany zaistniałe na wybranych posterunkach wodowskazowych.

Słowa kluczowe: Wisła, erozja denna, regulacja techniczna

\begin{abstract}
The article presents the results of calculations concerning vertical changes of the Vistula channel bottom in the Carpathian Foreland over the last 150 years. The study involved 31 water gauge stations located along the river section between Goczałkowice and Puławy. Analysis of vertical changes of the Vistula channel bottom was carried out with the generally accepted assumption that tendency in the course of annual minimum water stages at measurement station during long-term period reflects continuous channel deepening or its shallowing and also its stable vertical position in the same time period. The aim of the article is to identify the results of the regulation works which were started on the Vistula stretch analysed in the Carpathian Foreland around 1840, with special regard to selected gauging sites.
\end{abstract}

Key words: Vistula River, bottom erosion, technical regulation

\section{Wprowadzenie}

Rzeki należą do najbardziej mobilnych elementów sfery abiotycznej Ziemi (Trafas 1992), a morfologia ich koryt podlega ciągłym zmianom w czasie i przestrzeni (Wiejaczka, Kijowska 2011). Rzeki karpackie współcześnie cechuje skłonność do pogłębiania koryta i zmian położenia w planie (Klimek 1983, 1991, Punzet 1994, Łapuszek 2011, 2013). Zjawisko to rozpoczęło się wraz z ociepleniem klimatu na początku holocenu, a jego następstwem było ograniczenie dostawy zwietrzeliny do koryt i wyrównanie przepływu rzek. W rezultacie w korytach rzek zaczęło przeważać odprowadzanie materiału nad do- stawą ze stoków (Klimek 1983). Dążąc do zachowania równowagi pomiędzy przepływem wody a ilością transportowanego materiału, rzeki nieustannie dostosowują geometrię koryt w układzie poziomym i pionowym do zmiennego w czasie transportu materiału poprzez procesy erozji i sedymentacji (Williams, Wolman 1984, Klimek 1991, Kondolf 1997, Łapuszek 2013, Strużyński, Bartnik 2013).

W ciągu XIX i XX w. erozja koryt cieków karpackich została przyspieszona przez czynniki antropogeniczne. Do najczęściej wymienianych przyczyn zachwiania pionowej równowagi koryt rzecznych na świecie zalicza się regulację koryta polegającą na jego skróceniu, wy- 
prostowaniu i zwężeniu, przegrodzenie koryta zaporą wodną (Williams, Wolman 1984), eksploatację żwirów korytowych (Wyżga i in. 2008b, 2010, Korpak i in. 2009, Wiejaczka, Kijowska 2011), a także zmiany w użytkowaniu ziemi w zlewni rzeki (Klimek 1991). Jednak w największym stopniu pogłębianie koryta jest obecnie wynikiem regulacji technicznej rzeki (Brookes 2009), która rozumiana jest jako całokształt czynności zmierzających do opanowania i kontroli rzeki w celu ochrony przed jej niszczącą działalnością oraz przystosowania jej do pełnienia określonych funkcji, np. żeglugi lub spławu (Trafas 1975).

Badania nad pionową zmiennością koryt rzecznych, a w szczególności odcinków, gdzie wykazano stałe pogłębianie ich dna, powinny być systematycznie prowadzone w celu wykazania dynamiki tego procesu w bliższej i dalszej przyszłości. Znajomość tendencji zmian położenia koryta cieku jest istotna dla gospodarowania zasobami dna doliny i budownictwa wodnego (Jaeggi 1989, Brookes 2009). Jest szczególnie ważna w projektowaniu ujęć wody, mostów i prognozowaniu zmian położenia wód gruntowych na terenach przyległych. Badania te nabierają szczególnego znaczenia w świetle Ramowej Dyrektywy Wodnej, według której działania podejmowane przez człowieka powinny prowadzić do poprawy, a na pewno do niepogarszania stanu wód (Strużyński i in. 2013).

Celem pracy jest przedstawienie zmian położenia dna koryta Wisły na odcinku między Goczałkowicami i Puławami w ciągu ostatnich dziesięcioleci. Określenie tendencji zmian położenia koryta w czasie zostało przeprowadzone na podstawie analizy zmienności minimalnych rocznych stanów wody na posterunkach wodowskazowych w okresie wieloletnim (Punzet 1994, Łapuszek, Ratomski 2008, Łapuszek 2011, 2013).

\section{Obszar badań}

Długość Wisły na przedpolu Karpat na odcinku umownie ograniczonym posterunkami Goczałkowice i Puławy wynosi $416 \mathrm{~km}$, co stanowi około 40\% całego biegu rzeki (ryc. 1). Ten odcinek rzeki odprowadza wody z terenu Karpat Zachodnich i Wschodnich, Kotlin Podkarpackich i Wyżyn Polskich, a jego zlewnia ma powierzchnię ponad $50000 \mathrm{~km}^{2}$ (Łajczak 1995, 2006). Największy udział w dostawie wody i rumowiska do omawianego odcinka Wisły mają dopływy karpackie (Lajczak 1999).

Powyżej posterunku wodowskazowego w Goczałkowicach zlokalizowany jest największy na Wiśle przedgórskiej zbiornik wodny powstały poprzez spiętrzenie wód rzecznych zaporą w Goczałkowicach. Został on oddany do użytku w 1956 r., a jego pojemność całkowitą zaprojektowano na $165,5 \mathrm{mln} \mathrm{m}^{3}$. W okolicach Krakowa powstało począwszy od lat 50. XX w. sześć niskich stopni wodnych, które tworzą Kaskadę Górnej Wisły.

Pierwsze prace regulacyjne na przedgórskim odcinku Wisły zostały wykonane jeszcze w średniowieczu,

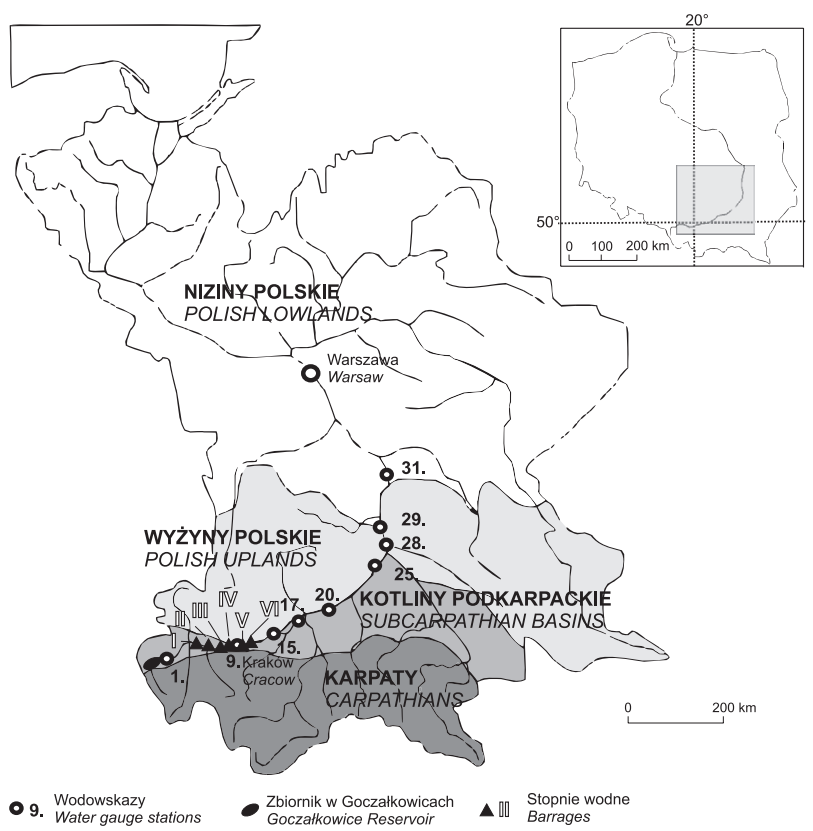

Ryc. 1. Obszar badań. Zlewnia Wisły na tle regionów geomorfologicznych i wybrane posterunki wodowskazowe

1 - Goczałkowice, 9 - Kraków-Tyniec, 15 - Sierosławice, 17 - Jagodniki, 20 - Szczucin, 25 - Sandomierz, 28 - Zawichost, 29 - Annopol, 31 - Puławy (numeracja zgodna z tab. 1). Wykaz wszystkich posterunków zawiera tab. 1. Stopnie wodne: I - Dwory, II - Smolice, III - Łączany, IV - Kościuszko, V - Dąbie, VI - Przewóz

Fig. 1. Study area. The Vistula River catchment against a bacground of geomorphic regions and selected gauging stations

1 - Goczałkowice, 9 - Kraków-Tyniec, 15 - Sierosławice, 17 - Jagodniki, 20 - Szczucin, 25 - Sandomierz, 28 - Zawichost, 29 - Annopol, 31 - Puławy (numbering as in tab. 1). List of all gauging sites is included in tab. 1. The barrages: I - Dwory, II - Smolice, III - Łączany, IV - Kościuszko, V - Dąbie, VI - Przewóz

za czasów panowania Kazimierza Wielkiego. Polegały one na budowie obwałowań, a ich głównym celem była ochrona przeciwpowodziowa. Miały one jednak tylko zasięg lokalny (Trafas 1992). Do właściwej regulacji rzeki przystąpiono dopiero około 1830 r., a bodziec do bardziej energicznych prac dała powódź w 1884 r. (Trafas 1975). W tym czasie Wisła była rzeką graniczną pomiędzy zaborem rosyjskim i austriackim, a w przypadku odcinka przełomowego rzeki przebiegała na peryferiach cesarstwa rosyjskiego, które nie było zainteresowane inwestowaniem w regulację rzeki nie przynoszącej dochodów (Warowna 2003). W efekcie prace regulacyjne przebiegały z różną intensywnością na poszczególnych jej odcinkach. Na mocy umów międzypaństwowych dokonano częściowej regulacji górnej Wisły - do Zawichostu. Po stronie austriackiej udało się uregulować około 79\% biegu rzeki, a po rosyjskiej zaledwie $50 \%$, i to w sposób nieciągły. Poniżej Zawichostu regulację rzeki rozpoczęto później i w znaczenie mniejszym zakresie niż na odcinkach śląskim i krakowskim rzeki (Lajczak 2006). Ponownie do prac regulacyjnych przystąpiono po I i II wojnie światowej, których działania spowodowały zniszczenie wielu urządzeń 
regulacyjnych (Trafas 1975). Prace regulacyjne na Wiśle są kontynuowane z różnym nasileniem do chwili obecnej (Łajczak 2006).

W ciągu blisko 200 lat prace regulacyjne na Wiśle przedgórskiej polegały na ścinaniu zakoli, a nawet prostowaniu biegu rzeki, umocnieniu brzegów, budowaniu wałów przeciwpowodziowych i urządzeń hydrotechnicznych, takich jak stopnie wodne, jazy, kanały żeglugowe lub elektrownie wodne (Trafas 1975, 1992, Warowna 2003, Łajczak 2006). Zakres prac doprowadził do skrócenia biegu rzeki, a także zwężenia koryta w celu zwiększenia jego głębokości, co przyczyniło się do naruszenia naturalnej równowagi dna (Lapuszek 2013).

\section{Materiały i metody badań}

Analizę przebiegu procesów erozyjnych przeprowadzono z założeniem podanym przez Punzeta (1994), że układ stanów niskich rocznych $\mathrm{z}$ wielolecia odpowiada położeniu dna, a zmiana stanów wody jest równoznaczna ze zmianami położenia dna w określonym przedziale czasu (Łapuszek, Ratomski 2008, Łapuszek 2011, 2013).

Dla wieloletnich ciągów stanów niskich rocznych określono funkcję regresji, opisującą położenia dna cieku w danym roku T. Funkcja Hi(T) określająca zależność stanu niskiego rocznego w danym roku obserwacyjnym od czasu (lata) w i-tym przedziale czasowym jest zapisana następująco (Łapuszek, Ratomski 2006):

$$
H_{i}(T)=H_{s r}(T)+\varepsilon
$$

gdzie:

$\varepsilon$ - składnik losowy (składnik resztowy, zwany resztą); $H_{s r}(T)$ - funkcja regresji wyrażona w postaci funkcji liniowej:

$$
H_{s r}(T)=E\left(H \cdot T^{-1}\right)=\alpha T+\beta
$$

gdzie:

$T$ - rok obserwacyjny;

$\alpha$-wskaźnik intensywności erozji lub akumulacji, $\mathrm{cm} \mathrm{a}^{-1}$; $\beta-$ stała, cm.

Wartość parametru $\alpha$ wskazuje na średnie roczne obniżanie lub wypłycanie dna cieku w roku T. Symbol $\mathrm{E}\left(\mathrm{H} \cdot \mathrm{T}^{-1}\right)$ oznacza warunkową wartość oczekiwaną stanu średniego $\mathrm{w}$ roku T, a parametry $\alpha$ i $\beta$ są szacowane metodą najmniejszych kwadratów (Łapuszek 2013). Badaniami objęto 31 profili wodowskazowych na Wiśle między Goczałkowicami i Puławami (ryc. 1, tab. 1), w których najdłuższe serie obserwacji stanów wody sięgają 150 lat. W opracowaniu wykorzystano dane od 1820 do 1995 r. W tak długim okresie w niektórych przekrojach wodowskazowych zaprzestano obserwacji stanów wody, niektóre posterunki uległy likwidacji w wyniku budowy niskich stopni wodnych. W tym czasie w różnych latach zakładano także nowe posterunki wodowskazowe. W obliczeniach uwzględniono wszystkie zmiany położenia zer wodowskazów oraz zmiany ich lokalizacji. Informacje na ten temat uzyskano w Instytucie Meteorologii i Gospodarki Wodnej.

\section{Wyniki}

W tabeli zbiorczej (tab. 1) zestawiono wartości średniego rocznego wskaźnika erozji dna koryta w badanym odcinku Wisły we wszystkich profilach wodowskazowych. Wyniki obliczeń dla wybranych wodowskazów, których lokalizację pokazano na rycinie 1 , zostały przedstawione również na rycinach 2 i 3 . Pozwalają one przeanalizować zmienność procesów erozyjnych wywołanych pracami regulacyjnymi przeprowadzonymi na Wiśle, a polegającymi na znacznym skróceniu biegu rzeki. Na podstawie równań regresji można bardziej szczegółowo wnioskować o efektach erozyjnych utworzenia na Wiśle zbiorników wodnych i stopni wodnych, a także o skutkach innych form regulacji koryta rzeki.

Na podstawie wstępnej analizy przebiegu zmienności minimalnych rocznych stanów wody w przekroju wodowskazowym Goczałkowice okres obserwacyjny podzielo-

a)

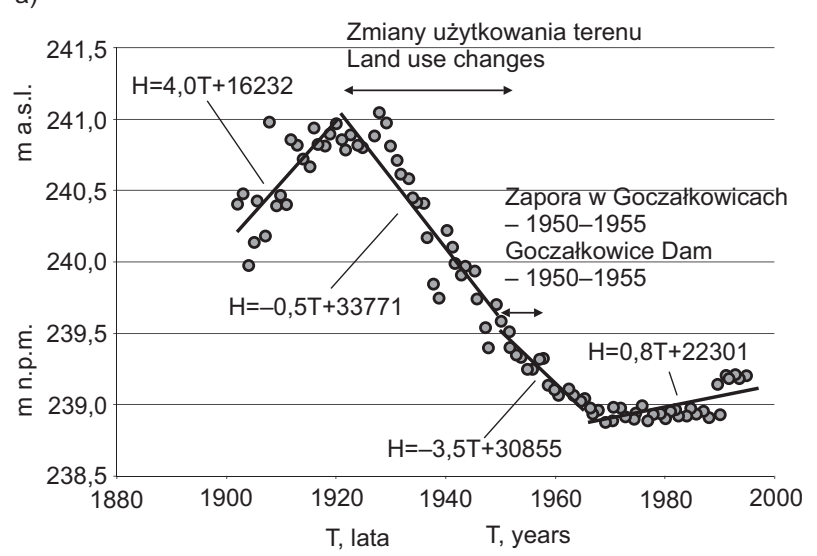

b)

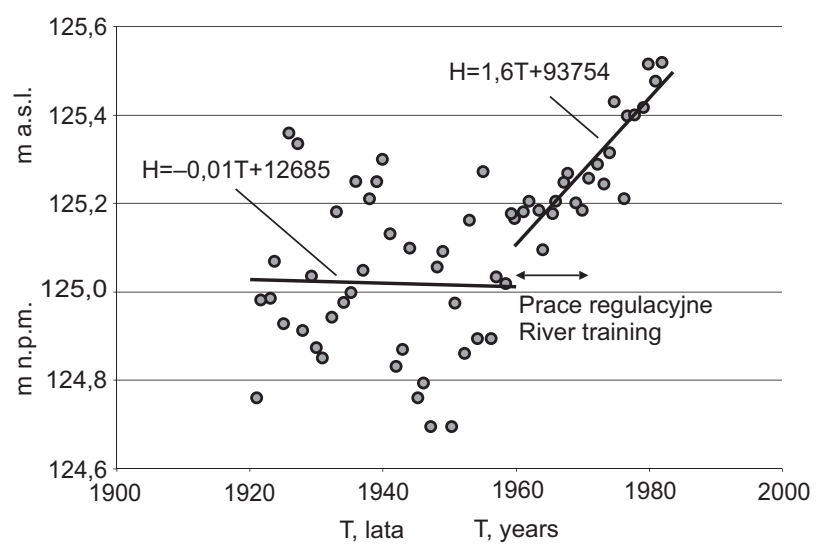

Ryc. 2. Przebieg minimalnych rocznych stanów wody oraz funkcje regresji na posterunkach wodowskazowych: a) Goczałkowice, b) Solec

Fig. 2. Course of minimum annual water stages and regression equations for gauging stations on the Vistula River: a) Goczałkowice, b) Solec 
Tabela 1. Średnie roczne tempo obniżania dna koryta Wisły w badanych przekrojach wodowskazowych. Ujemne wartości w ostatniej kolumnie oznaczają tempo pogłębiania koryta, a wartości dodatnie tempo wypłycania koryta

Table 1. The average annual rate of the Vistula channel bottom lowering in the analysed measurement stations. The negative values in the last column mean the rate of channel's deepening and the positive values mean the rate of channel's shallowing

\begin{tabular}{|c|c|c|c|c|}
\hline Lp. & Wodowskaz & Okres obserwacyjny & Równanie intensywności erozji dennej & Wskaźnik obniżania dna koryta $\left[\mathrm{cm} \mathrm{a}^{-1}\right]$ \\
\hline 1 & Goczałkowice & $1902-1995$ & $\mathrm{H}=-2,463 \mathrm{~T}+24094$ & $-2,46$ \\
\hline 2 & Jawiszowice & $1887-1995$ & $\mathrm{H}=0,210 \mathrm{~T}+23374$ & 0,21 \\
\hline 3 & Nowy Bieruń & $1871-1995$ & $\mathrm{H}=0,147 \mathrm{~T}+22700$ & 0,15 \\
\hline 4 & Pustynia & 1888-1994 & $\mathrm{H}=-1,537 \mathrm{~T}+22626$ & $-1,54$ \\
\hline 5 & Dwory & $1888-1980$ & $\mathrm{H}=-1,517 \mathrm{~T}+22426$ & $-1,52$ \\
\hline 6 & Smolice & 1874-1994 & $\mathrm{H}=-1,251 \mathrm{~T}+21723$ & $-1,25$ \\
\hline 7 & Okleśna & $1911-1958$ & $\mathrm{H}=-0,599 \mathrm{~T}+21474$ & $-0,60$ \\
\hline 8 & Czernichów & $1892-1960$ & $H=-1,763 \mathrm{~T}+20842$ & $-1,76$ \\
\hline 9 & Kraków-Tyniec & $1898-1989$ & $H=-3,032 T+20264$ & $-3,03$ \\
\hline 10 & Kraków-Bielany & 1956-1994 & $\mathrm{H}=1,853 \mathrm{~T}+19816$ & 1,90 \\
\hline 11 & Kraków & $1823-1964$ & $\mathrm{H}=-2,973 \mathrm{~T}+19882$ & $-2,97$ \\
\hline 12 & Kraków-Przewóz & $1899-1953$ & $\mathrm{H}=-2,545 \mathrm{~T}+19382$ & $-2,54$ \\
\hline 13 & Niepołomice & $1888-1953$ & $H=-1,953 T+19010$ & $-2,00$ \\
\hline 14 & Nowa Wieś & $1898-1953$ & $\mathrm{H}=-0,325 \mathrm{~T}+18510$ & $-0,33$ \\
\hline 15 & Sierosławice & 1876-1994 & $\mathrm{H}=-1,423 \mathrm{~T}+18029$ & $-1,42$ \\
\hline 16 & Popędzynka & $1868-1994$ & $\mathrm{H}=-0,531 \mathrm{~T}+17703$ & $-0,53$ \\
\hline 17 & Jagodniki & $1868-1994$ & $H=-1,085 T+17330$ & $-1,09$ \\
\hline 18 & Karsy & 1869-1994 & $\mathrm{H}=-1,479 \mathrm{~T}+16992$ & $-1,48$ \\
\hline 19 & Pawłów & $1894-1960$ & $\mathrm{H}=-0,530 \mathrm{~T}+16618$ & $-0,53$ \\
\hline 20 & Szczucin & 1869-1994 & $\mathrm{H}=-1,069 \mathrm{~T}+16194$ & $-1,07$ \\
\hline 21 & Otałęż & $1898-1960$ & $\mathrm{H}=-0,524 \mathrm{~T}+15742$ & $-0,52$ \\
\hline 22 & Ostrówek & $1888-1980$ & $\mathrm{H}=-0,069 \mathrm{~T}+15359$ & $-0,07$ \\
\hline 23 & Koło & $1898-1990$ & $\mathrm{H}=-1,284 \mathrm{~T}+14971$ & $-1,28$ \\
\hline 24 & Dzików & $1865-1987$ & $H=-0,969 T+14519$ & $-0,97$ \\
\hline 25 & Sandomierz & $1878-1994$ & $\mathrm{H}=-0,999 \mathrm{~T}+14140$ & $-1,00$ \\
\hline 26 & Dąbrowa Wrzawska & $1888-1960$ & $\mathrm{H}=-0,450 \mathrm{~T}+13963$ & $-0,45$ \\
\hline 27 & Chwałowice & $1888-1943$ & $\mathrm{H}=0,07 \mathrm{~T}+13694$ & 0,07 \\
\hline 28 & Zawichost & 1881-1994 & $\mathrm{H}=-0,689 \mathrm{~T}+13656$ & $-0,69$ \\
\hline 29 & Annopol & 1923-1990 & $\mathrm{H}=0,102 \mathrm{~T}+13338$ & 0,10 \\
\hline 30 & Solec & 1921-1982 & $\mathrm{H}=0,674 \mathrm{~T}+12490$ & 0,67 \\
\hline 31 & Puławy & 1919-1990 & $\mathrm{H}=0,394 \mathrm{~T}+11546$ & 0,39 \\
\hline
\end{tabular}

no na cztery przedziały czasowe: 1902-1920, 1921-1949, 1950-1965, 1966-1995 (ryc. 2). Dla każdego z nich określono funkcję regresji, opisującą intensywność przebiegu erozji dennej lub akumulacji. W drugim i trzecim $z$ tych przedziałów czasu dominowała erozja denna, natomiast w pozostałych przeważały procesy akumulacji materiału dennego.

W przekroju wodowskazowym Solec okres obserwacyjny został podzielony na następujące przedziały czasowe: 1921-1960 i 1961-1982 (ryc. 2). Na podstawie przedstawionych wyników można stwierdzić, że w pierwszym z tych przedziałów czasu zachodziło powolne pogłębianie koryta Wisły. W następnych latach rozpoczęło się szybkie wypłycanie koryta.

Zmiany w położeniu dna koryta Wisły na terenie Krakowa ustalono w przekrojach wodowskazowych: Kraków i Kraków-Bielany. Okres obserwacyjny dla obu wodowskazów obejmuje lata od 1823 do 1995. Został on podzielony na przedziały: 1823-1870, 1871-1945, 19461964, 1956-1975 i 1976-1995. Wyniki obliczeń przedstawiono na rycinie 3 . Na tej podstawie można stwierdzić, że w przeważającym okresie dno koryta Wisły w Krakowie ulegało obniżaniu. Tylko w latach 1946-1964 (Kraków) i 1956-1975 (Kraków-Bielany) zaobserwowano wypłycanie koryta Wisły.

\section{Dyskusja}

Obserwując zmiany położenia koryta Wisły przedgórskiej na przestrzeni ostatnich dziesięcioleci, można stwierdzić, że na przeważającym odcinku ulegało ono obniżaniu. W blisko $80 \%$ spośród zanalizowanych profili wodowskazowych zaobserwowano tendencję do pogłębiania się koryta. Średnio wyniosło ono 2-4 m i miejscami doprowadziło do odsłonięcia gruboziarnistych bruków, a nawet mioceńskiego podłoża (Starkel 2001).

Główną przyczyną występowania erozji dna koryta na tym odcinku rzeki było jego znaczne skrócenie sztucznymi przekopami, a także dwu-, a nawet trzykrotne jego zwężenie. Negatywnymi skutkami tego procesu w skali lokalnej jest podmywanie budowli regulacyjnych i fila- 


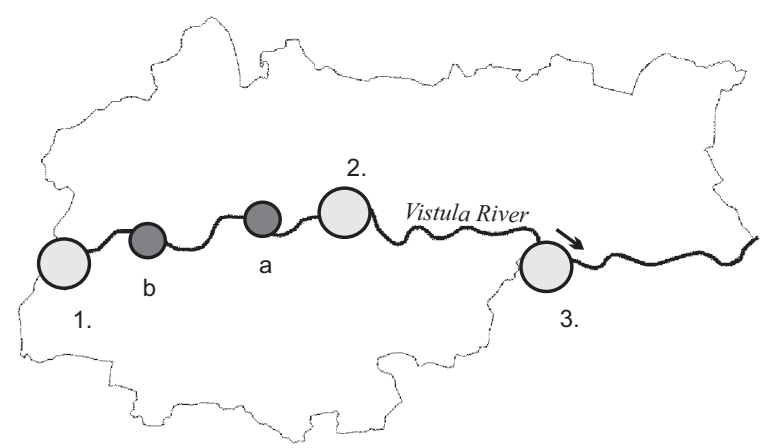

a)

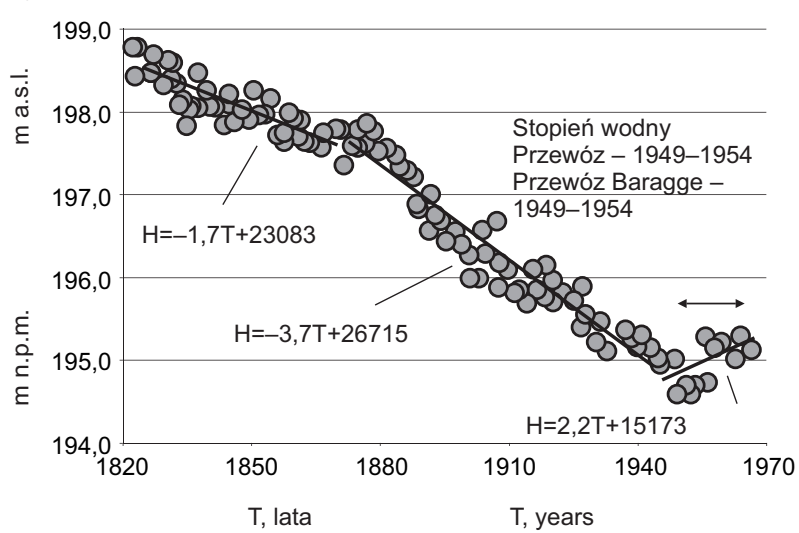

b)

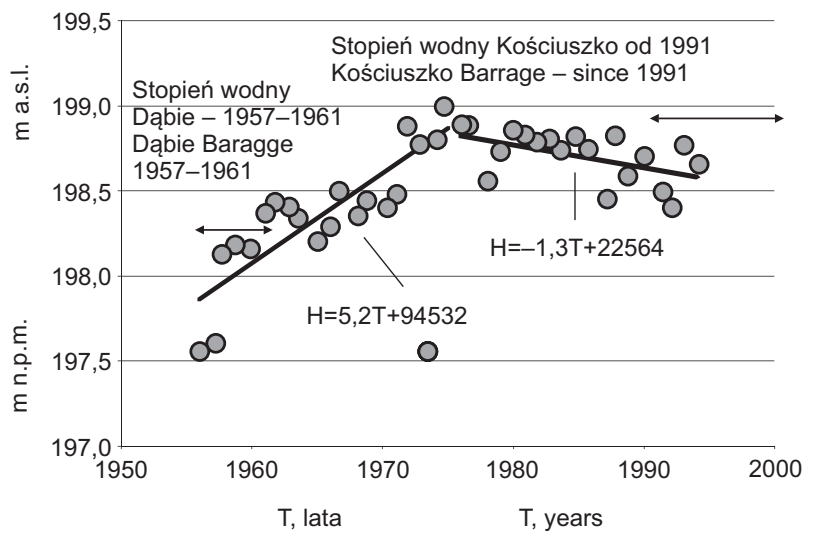

Ryc. 3. Lokalizacja stopni wodnych na Wiśle w Krakowie 1 - Kościuszko, 2 - Dąbie, 3 - Przewóz. Przebieg minimalnych rocznych stanów wody oraz funkcje regresji: a) w profilu wodowskazowym Kraków, b) w profilu wodowskazowym Kraków-Bielany

Fig. 3. The barrages on the Vistula in Kraków

1 - Kościuszko, 2 - Dąbie, 3 - Przewóz. Course of minimum annual water stages and regression equations: a) Kraków gauging station, b) in Kraków-Bielany gauging station

rów mostów oraz wynurzanie ujęć brzegowych, a także obniżanie średniego poziomu wód gruntowych oraz ubożenia zbiorowisk roślinnych i zwierzęcych (Jaeggi 1989, Petts 1989, Bartnik, Książek 2007, Wyżga i in. 2008a, Brookes 2009).

Największe tempo pogłębiania dna koryta Wisły zaobserwowano w okolicach Krakowa w przekrojach wodowskazowych (tab. 1): Czernichów (-1,76 $\left.\mathrm{cm} \mathrm{a}^{-1}\right)$, Kraków-Tyniec $\left(-3,03 \mathrm{~cm} \mathrm{a}^{-1}\right)$ i Niepołomice $(-2,0 \mathrm{~cm}$ $\mathrm{a}^{-1}$ ). Koryto Wisły od 1823 do 1964 r. w profilu Kraków uległo obniżeniu o ponad 3,6 m. Jest to efekt niewłaściwie prowadzonej regulacji zapoczątkowanej poniżej Krakowa w okolicy Niepołomic, polegającej na znacznym skróceniu biegu Wisły poprzez wykonanie przekopów zakoli (Trafas 1975), która doprowadziła do zaburzenia równowagi naturalnej pomiędzy prędkością przepływu a oporami podłoża.

Proces erozji koryta Wisły w Krakowie został zahamowany około 1950 r. na skutek wybudowania niskiego stopnia wodnego Przewóz, a następnie kolejnego stopnia - Dąbie (ryc. 3). Tempo akumulacji stopniowo wzrastało od 2,2 $\mathrm{cm} \mathrm{a}^{-1}$ do 5,2 $\mathrm{cm} \mathrm{a}^{-1}$, co doprowadziło do wypłycenia koryta o około $1 \mathrm{~m}$. Proces erozji koryta Wisły został ponownie zainicjowany wraz z budową stopnia wodnego Kościuszko powyżej Krakowa. Według Kondolfa (1997) zjawisko to nazywane hungry waters powstaje w wyniku zatrzymania części materiału transportowanego przez zaporę lub stopnie wodne i prowadzi do erozji dna i brzegów rzeki (Williams, Wolman 1984, Babiński 1992, 1997). W wyniku zahamowania dostawy rumowiska pogłębianie koryta w Krakowie wynosi obecnie około $-1,3 \mathrm{~cm} \cdot \mathrm{rok}^{-1}$.

Oprócz regulacji technicznej koryta ważnym czynnikiem determinującym zmiany funkcjonowania koryta rzeki jest użytkowanie ziemi w zlewni (Brookes 2009), co widoczne jest na wykresie przedstawiającym przebieg minimalnych rocznych stanów wody Wisły w profilu wodowskazowym Goczałkowice (ryc. 2). Pod koniec XIX i na początku XX w. upowszechnienie uprawy roślin okopowych zwiększyło, jak na innych obszarach Karpat fliszowych (Klimek 1983, 1991), szybkość spływu wód opadowych w okresie letnim, czego skutkiem były częstsze wezbrania oraz większa ilość gleby zmywanej ze stoków do den dolin rzecznych. W efekcie doprowadziło to do intensyfikacji transportu dennego i tworzenia nowych łach w korycie rzeki. Proces ten bardzo wyraźnie daje się zauważyć w korycie Wisły w strefie przekroju wodowskazowego Goczałkowice (ryc. 3) w postaci wzrostu tempa akumulacji do około $4,0 \mathrm{~cm} \mathrm{a}^{-1}$.

Odwrotne tendencje w użytkowaniu ziemi w Karpatach, tzn. zwiększanie powierzchni upraw zielonych, łąk i pastwisk w latach 20. XX w., ograniczyły erozję gleb i dostawę materiału do den dolin. Uwolniona w ten sposób energia wody płynącej skierowana została na pogłębianie koryta, co jest szczególnie widoczne w górskich dopływach Wisły na przedpolu Karpat (Klimek 1983, 1991). W przypadku Wisły w Goczałkowicach tempo pogłębiania koryta w tym okresie wyniosło aż $5 \mathrm{~cm} \mathrm{a}^{-1}$ (ryc. 3).

Proces ten kontynuowany był po wybudowaniu zbiornika zaporowego w Goczałkowicach, ale z mniejszą intensywnością $\left(-3,5 \mathrm{~cm} \mathrm{a}^{-1}\right)$. Po $1960 \mathrm{r}$. zaobserwowano nawet powolne wypłycanie koryta Wisły poniżej tego zbiornika. Według Babińskiego (2007) proces erozji wgłębnej poniżej zapór w czasie dłuższym niż kilka lat odznacza się dużą nieregularnością, jednak z ogólną tendencją do wygasania. Do takiego stanu rzeczy może prowadzić częściowe zahamowanie erozji podczas budowy zapory, a następnie napełnianie zbiornika zaporowego. 
Dopiero po okresie trwającym od kilku miesięcy do kilkunastu lat proces ten może uaktywnić się ponownie.

Regulacja techniczna koryta Wisły na przedpolu Karpat dała impuls do pogłębiania koryta, które objęło prawie cały bieg omawianego odcinka rzeki. Tylko na krótkim odcinku Wisły w Kotlinie Oświęcimskiej i dłuższym odcinku od Zawichostu po Puławy lokalnie koryto nie pogłębia się, a nawet ulega wypłycaniu. Przyczyną tego zjawiska w Kotlinie Oświęcimskiej w profilach wodowskazowych Jawiszowice $\left(0,21 \mathrm{~cm} \mathrm{a}^{-1}\right)$ i Nowy Bierun $\left(0,15 \mathrm{~cm} \mathrm{a}^{-1}\right)$ jest akumulacja materiału wyerodowanego z dna koryta Wisły poniżej zapory w Goczałkowicach, a także oddziaływanie stopni wodnych Dwory i Smolice w dalszym biegu Wisły.

W przypadku odcinka rzeki w Małopolskim Przełomie Wisły wypłycanie koryta w strefach przekrojów wodowskazowych jest skutkiem dużych różnic w zaawansowaniu prac regulacyjnych, rozpoczętych jeszcze w XIX w. w okolicach Krakowa. Przykład tego stanu reprezentuje wodowskaz w Solcu (ryc. 2), gdzie po względnej stabilizacji koryta wraz z rozpoczęciem intensywnych prac regulacyjnych powyżej wspomnianego wodowskazu w latach 60. XX w. odnotowano agradacje dużych ilości materiału w korycie Wisły (Warowna 2003). Największe tempo agradacji stwierdzono w Solcu nad Wisłą (0,67 $\left.\mathrm{cm} \mathrm{a}^{-1}\right)$ i mniejsze w Puławach $\left(0,39 \mathrm{~cm} \mathrm{a}^{-1}\right)$ i Annopolu $\left(0,10 \mathrm{~cm} \mathrm{a}^{-1}\right)$. Zaburzenie naturalnej równowagi dna koryta Wisły na tym obszarze jest szczególnie niebezpieczne, ponieważ w przeciwieństwie do planowanych efektów regulacji rzeki przyczyniło się do wzrostu zagrożenia powodziowego (Łajczak 1995, 2006, 2012).

\section{Podsumowanie i wnioski}

Zmiany w położeniu dna koryt rzecznych obserwuje się nieustannie, a proces ten przebiega $\mathrm{z}$ różną intensywnością. Gospodarcze wykorzystanie rzek i potoków spowodowało jednak degradację naturalnej równowagi koryt i przyspieszyło ich przemodelowanie. Jest to spowodowane zarówno zmianami zachodzącymi w użytkowaniu terenu, jak i pracami regulacyjnymi w korycie rzeki.

W artykule przedstawiono analizę zmienności położenia dna koryta Wisły w jej przedgórskim biegu w czasie, na podstawie przebiegu minimalnych rocznych stanów wody w ponad 100-letnim okresie na 31 posterunkach wodowskazowych. Wyniki przeprowadzonych analiz wykazują, że główną przyczyną intensywnej erozji dennej w ciągu ostatnich 150 lat była regulacja techniczna koryta. Poprzez wykonanie przekopów, a nawet prostowanie biegu rzeki i zwężenie koryta, przyspieszono odpływ wód ze zlewni i doprowadzono do wzrostu zdolności transportowej rzeki.

Koryto Wisły przedgórskiej nie osiągnęło ponownie równowagi po wykonanych wcześniej pracach regulacyjnych. Na niemal całej długości analizowanego odcinka rzeki koryto nieustannie podlega intensywnej erozji wgłębnej, wywołując zagrożenia w stabilności obiektów hydrotechnicznych, obniżając poziom wód gruntowych i zmniejszając retencję wód wezbraniowych. Z drugiej strony wypłycanie koryta na odcinku przełomowym przez Wyżyny Polskie prowadzi do wzrostu zagrożenia powodziowego.

Ingerencja człowieka w procesy korytowe na danym odcinku rzeki wywołuje zmiany zarówno powyżej, jak i poniżej miejsca tych działań, czego przykładem mogą być zmiany koryta Wisły pod wpływem oddziaływania stopni wodnych w Krakowie. Po pierwszym okresie, kiedy koryto rzeki dążyło do stabilizacji, rozpoczęło się ponowne pogłębianie koryta.

Przystępując zatem do prac regulacyjnych, należy wcześniej przeprowadzić dokładne analizy oraz przewidzieć możliwe scenariusze rozwoju koryta i ich ewentualne skutki. Według założeń Ramowej Dyrektywy Wodnej działania te nie mogą jednak pogorszyć stanu ekologicznego systemu rzecznego oraz powinny zapobiegać degradowaniu ekosystemów rzecznych i nadrzecznych.

\section{Podziękowania}

Dziękuję Dyrekcji Instytutu Meteorologii i Gospodarki Wodnej - Państwowego Instytutu Badawczego w Warszawie za udostępnienie danych o minimalnych stanach rocznych wody na wybranych posterunkach wodowskazowych Wisły, a prof. dr. hab. Adamowi Łajczakowi oraz recenzentom za uwagi do pierwotnej wersji artykułu.

\section{Literatura}

Babiński Z., 1992. Współczesne procesy korytowe Dolnej Wisły. Prace Geograficzne 157: 50.

Babiński Z., 1997. Procesy erozyjno-akumulacyjne poniżej stopnia wodnego Włocławek. Ich konsekwencje i wpływ na morfodynamikę planowanego zbiornika Nieszawa. IGiGP PAN, Toruń: 5.

Babiński Z., 2007. Erozja wgłębna poniżej zbiorników wodnych na przykładzie wybranych zapór świata. Nauka Przyroda Technologie 1(2) 11 .

Bartnik W., Książek L., 2007. Regulacja rzek i potoków górskich w warunkach równowagi hydrodynamicznej. Infrastruktura i Ekologia Terenów Wiejskich 4/2/: 15-26.

Brookes A., 2009. River Channel Change. W: P. P. Calow (red.), Rivers Handbook: The Science and Management of River Environments. Wiley-Blackwell, 12: 55-75.

Jaeggi M.N.R., 1989. Channel Engineering and Erosion Control. W: J.A. Gore, G.E. Petts (red.), Alternatives in Regulated River Management. CRC Press, Boca Raton, Florida: 163-183.

Klimek K., 1983. Erozja wgłębna dopływów Wisły na przedpolu Karpat. W: Z. Kajak (red.) Ekologiczne podstawy zagospodarowania Wisły i jej dorzecza. PWN, Warszawa: 97-108.

Klimek K., 1991. Typy koryt rzecznych. W: I. Dynowska, M. Maciejewski (red.), Dorzecze górnej Wisły. PWN, Warszawa-Kraków, cz. 1: 231-234.

Kondolf G.M., 1997. Hungry water: Effects of dams and gravel mining on river channel. Enviromental Managment 4(21): 533-551.

Korpak J., Krzemień K., Radecki-Pawlik A., 2009. Wpływ budowli regulacyjnych i poboru rumowiska na koryta rzek i potoków górskich. Gospodarka Wodna 7: 274-281.

Łajczak A., 1995. The Impact of River Regulation, 1859-1990, on the Channel and Floodplain of the Upper Vistula River, Southern Poland. W: E.J. Hickin (red.), River Geomorphology. Wiley, Chichester: 209-233. 
Łajczak A., 1999. Współczesny transport i sedymentacja materiału unoszonego w Wiśle i głównych dopływach. Monografie Komitetu Gospodarki Wodnej PAN 15: 215.

Łajczak A., 2006. Regulacja rzeki a zagrożenie powodziowe na przykładzie Wisły między Skoczowem i Puławami. Infrastruktura i Ekologia Terenów Wiejskich 4/1/: 197-214.

Łajczak A., 2012. Use of Piedmont Section of the Vistula in Southern Poland to Examine the Effects of River Channelization on Flood Risk. W: T. Wong (red.), Flood Risk and Flood Management. Publ. Nova Series, New York, USA: 88-106.

Łapuszek M., 2011. Zmiany erozyjne dna koryta Sanu z uwzględnieniem czynników antropogenicznych. Gospodarka Wodna 1: 22-26.

Łapuszek M., 2013. Wpływ czynników antropogenicznych na równowagę koryt dopływów górnej Wisły. Woda-Środowisko-Obszary Wiejskie 13(1/41): 75-88.

Łapuszek M., Ratomski J., 2006. Metodyka określania i charakterystyka przebiegu oraz prognoza erozji dennej rzek górskich dorzecza górnej Wisły. Monografia 332. Seria Ochrony Srodowiska, Kraków: 112.

Łapuszek M., Ratomski J., 2008. Zmiany erozyjne dna koryta Soły. Gospodarka Wodna 2: 54-57.

Petts G.E., 1989. Perspectives for Ecological Management of Regulated Rivers. W: J.A. Gore, G.E. Petts (red.), Alternatives in Regulated River Management. CRC Press, Boca Raton, Florida: 3-26.

Punzet J., 1994. Podsumowanie wykonanych badań nad zmiennością koryt rzek karpackich w XX wieku. Gospodarka Wodna 4: 16-21.

Starkel L., 2001. Historia doliny Wisły od ostatniego zlodowacenia do dziś. Monografie 2: 195-203. IGiPZ PAN, Warszawa.
Strużyński A., Bartnik W., Kulesza K., Czoch K., 2013. Równowaga hydrodynamiczna ważnym parametrem kształtującym stan ekologiczny cieków karpackich. Rocznik Ochrony Środowiska 15: 2591-2610.

Trafas K., 1975. Zmiany biegu koryta Wisły na wschód od Krakowa w świetle map archiwlanych i fotointerpretacji. Zeszyty Naukowe Uniwersytetu Jagiellońskiego, Prace Geograficzne 40.

Trafas K., 1992. Zmiany biegu Wisły pomiędzy ujściem Przemszy a Sandomierzem W: Zmiany biegu górnej Wisły i ich skutki. Wydawnictwo Uniwersytetu Warszawskiego, Warszawa: 31-42.

Warowna J., 2003. Wpływ zabudowy hydrotechnicznej na warunki sedymentacji w korycie powodziowym Wisły na odcinku ZawichostPuławy. Wyd. UMCS, Lublin: 25-28.

Wiejaczka Ł., Kijowska M., 2011. Zmiany położenia dna koryt rzek karpackich w świetle analizy stanów niskich. Monitoring Środowiska Przyrodniczego, KTN, Kielce 12: 137-143.

Williams G.P., Wolman M.G., 1984. Downstream effects of dams on alluvial rivers. US Geological Survey Professional Paper 1286: 7-26.

Wyżga B., Radecki-Pawlik A., Zawiejska J., 2008a. Dlaczego konieczna jest rewitalizacja rzek karpackich? Prace Komisji Krajobrazu Kulturowego 10: 275-282.

Wyżga B., Zawiejska J., Radecki-Pawlik A., 2008b. Określenie wielkości wcięcia się rzek i jego wpływu na hydraulikę przepływów wezbraniowych - przykłady z rzek karpackich. Landform Analysis 9: 402-405.

Wyżga B., Hajdukiewicz H., Radecki-Pawlik A., Zawiejska J., 2010. Eksploatacja osadów z koryt rzek górskich - skutki środowiskowe i procedury oceny. Gospodarka Wodna 6: 243-249. 